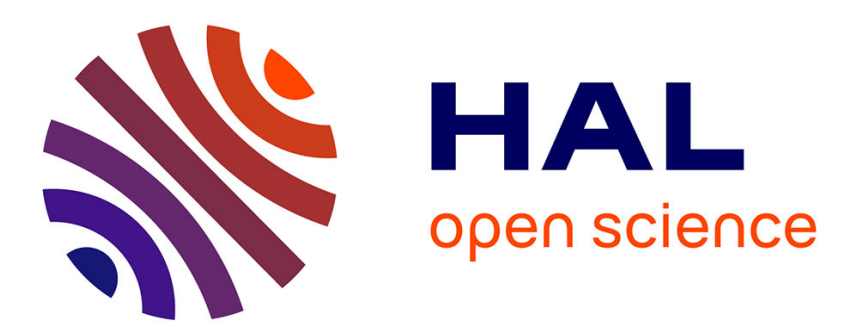

\title{
First record of the genus Bak Yunker (Acariformes: Prostigmata: Cheyletidae) from Iran with description of a new species
}

Saeid Paktinat-Saeij, Mohammad Bagheri, Michael Skvarla

\section{- To cite this version:}

Saeid Paktinat-Saeij, Mohammad Bagheri, Michael Skvarla. First record of the genus Bak Yunker (Acariformes: Prostigmata: Cheyletidae) from Iran with description of a new species. Acarologia, 2017, 57 (4), pp.847-853. 10.24349/acarologia/20174199 . hal-01598391

\section{HAL Id: hal-01598391 \\ https://hal.science/hal-01598391}

Submitted on 29 Sep 2017

HAL is a multi-disciplinary open access archive for the deposit and dissemination of scientific research documents, whether they are published or not. The documents may come from teaching and research institutions in France or abroad, or from public or private research centers.
L'archive ouverte pluridisciplinaire HAL, est destinée au dépôt et à la diffusion de documents scientifiques de niveau recherche, publiés ou non, émanant des établissements d'enseignement et de recherche français ou étrangers, des laboratoires publics ou privés. 


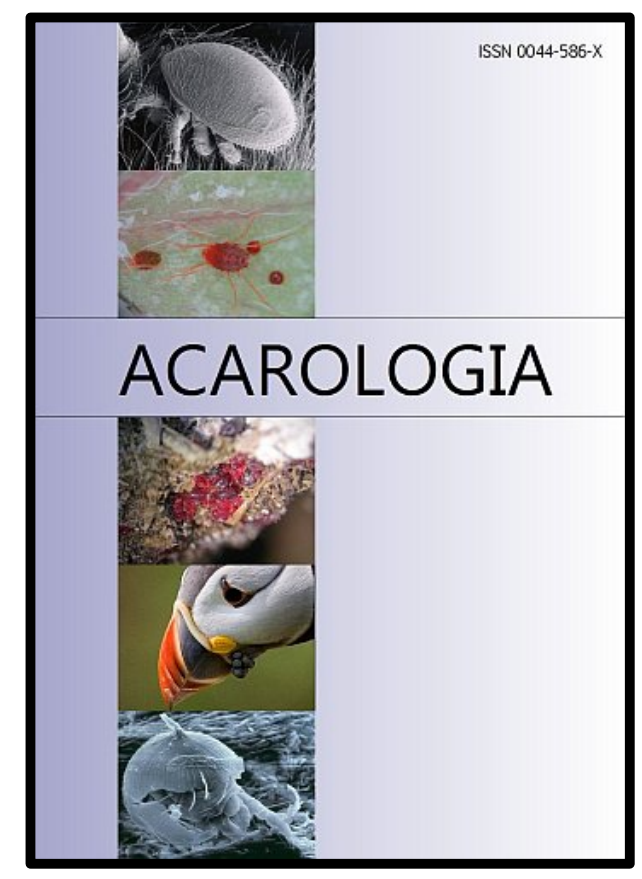

\section{ACAROLOGIA}

A quarterly journal of acarology, since 1959

Publishing on all aspects of the Acari

All information:

http://www1.montpellier.inra.fr/CBGP/acarologia/ acarologia@supagro.inra.fr

\section{OPEN ACCESS}

\section{Acarologia is proudly non-profit, with no page charges and free open access}

Please help us maintain this system by encouraging your institutes to subscribe to the print version of the journal and by sending us your high quality research on the Acari.

Subscriptions: Year 2017 (Volume 57): $380 €$ http://www1.montpellier.inra.fr/CBGP/acarologia/subscribe.php

Previous volumes (2010-2015): $250 € /$ year (4 issues)

Acarologia, CBGP, CS 30016, 34988 MONTFERRIER-sur-LEZ Cedex, France

The digitalization of Acarologia papers prior to 2000 was supported by Agropolis Fondation under the reference ID 1500-024 through the « Investissements d'avenir » programme

(Labex Agro: ANR-10-LABX-0001-01)
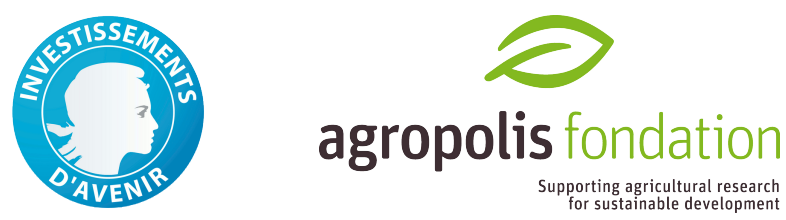

Acarologia is under free license and distributed under the terms of the

Creative Commons-BY-NC-ND which permits unrestricted non-commercial use, distribution, and reproduction in any medium, provided the original author and source are credited. 


\title{
First record of the genus Bak Yunker (Acariformes: Prostigmata: Cheyletidae) from Iran with description of a new species
}

\author{
Saeid PAKTINAT-SAeij ${ }^{1 \bowtie}$, Mohammad BAGHeRI ${ }^{2}$ and Michael SKVARLA ${ }^{3}$
}

(Received 19 February 2017; accepted 28 March 2017; published online 04 July 2017; edited by Farid FARAJI)

\footnotetext{
${ }^{1}$ Young Researchers and Elite Club, Maragheh Branch, Islamic Azad University, Maragheh, Iran. (凶) saeedpaktinat@yahoo.com, ${ }^{2}$ Department of Plant Protection, Faculty of Agriculture, University of Maragheh, Maragheh, Iran. mbagheri20022002@yahoo.com ${ }^{3}$ Department of Entomology, University of Maryland, 4112 Plant Sciences Building, College Park, MD 20742, USA. mskvarla36@gmail.com
}

\begin{abstract}
A new species, Bak iranica n. sp. (Acariformes: Prostigmata: Cheyletidae) is described on the basis of adult males from Amol, Mazandaran province, northern Iran. The new species can be distinguished from other species by the following features: having one seta on each trochanter, tarsi I-IV with $9(+1 \omega)-7(+1 \omega)-7(+1 \omega)-7(+1 \omega)$; a palpal claw with two basal teeth and most of the dorsal body setae slightly lanceolate and barbed. Additionally, a key to world species (females and males) of the genus Bak Yunker is provided. This genus is recorded from Iran for the first time.
\end{abstract}

KEYWORDS - Bak; Cheyletidae; Iran; key; new species; taxonomy

ZOOBANK — 15663805-55C1-429B-B8C2-E60139342D4B

\section{INTRODUCTION}

Currently, the family Cheyletidae (Acariformes: Cheyletoidea) includes more than 440 species in 75 genera (Zhang et al. 2011; Bochkov 2005). Most of these mites are free-living predators although some are permanent ectoparasites of small mammals and birds (Skoracki et al. 2012; Bochkov and Abramov 2016).

The genus Bak was erected by Yunker (1961), with Bak sanctaehelenae Yunker, 1961 as the type species collected from USA (California). This genus comprises 12 species (Bak ligysculatus Flechtmann, 1971 is nomen nudum because it was described in an unpublished thesis (Fain and Bochkov 2001)). Eleven species are described on the basis of female specimens and only B. nadchatrami is described based on male. Overall, males are described for six species. The genus is distributed in the Nearctic, Neotropical and Oriental regions, where most species inhabit organic debris and only occasionally are found in house dusts (Fain and Bochkov 2001; Bochkov and Otto 2010).

During taxonomic studies of cheyletid mites from northern Iran, a new species of Bak was discovered. Herein, we describe B. iranica n. sp., the first species of $B a k$ recorded from Iran, and provide an identification key to Bak species of the world.

\section{MATERIALS AND METHODS}

Soil and rotten leaves were taken from Amol county, Mazandaran Province. Mites were extracted by using a Berlese-Tullgren funnel and preserved in AGA 
solution (Smiley 1992). Specimens were cleared in lactophenol fluid, mounted in Hoyer's medium (Walter and Krantz 2009), and were examined under a phase contrast microscope (Olympus BX41). Drawings were made with a camera lucida and differential interference contrast (DIC) optics. The body length of specimens was measured from the apex of subcapitulum to posterior margin of idiosoma, the length of the gnathosoma was measured from the base to the tip of the subcapitulum, the width of the body at its broadest level, and the legs from the ventral insertion of coxae to the base of the pretarsi. In the description below, the idiosomal setation follows Grandjean (1939) as adapted for Prostigmata by Kethley (1990). The nomenclature for leg setae follows that of Grandjean (1944). All measurements are given in micrometres $(\mu \mathrm{m})$. Measurements (range) of paratype are given in brackets following that of holotype.

\section{RESULTS}

\section{Family Cheyletidae Leach, 1815}

\section{Genus Bak Yunker, 1961}

Type species: Bak sanctaehelenae Yunker, 1961

\section{Bak iranica n. sp. \\ (Figs. 1-2)}

Zoobank: 97ACFECD-69FB-4795-8989-8837B8911620

Diagnosis (male) - Body (including gnathosoma) 407 (371) long, 136 (112) wide; gnathosoma 130 (113) long, 77 (58) wide; propodonotal shield 141 (148) long, 76 (63) wide; median plate 27 (23) long, 17 (12) wide; palp 97 (81) long; palp femur 43 (38) long, 33 (29) wide; dorsal seta on palpal femur $(d F)$ ? (30) long. Length of legs I-IV: 167 (155); 123 (117); 158 (144); 156 (140). Dorsal seta on femur IV (dFIV) 30 (26).

\section{Description. Male $(n=2)$.}

Dorsum (Figs. 1A-B, 2A) - Dorsum with a single propodonotal shield and one small weakly sclerotized hysteronotal shield situated posteriorly. Eyes absent. Dorsal setae slightly lanceolate and finely barbed. Propodonotal shield in shape of elongate pentagon with rounded posterior margin, broken longitudinal striae, and bearing five pairs of setae (vi, ve, sci, sce and c1); setae c2 smooth filiform, situated ventrally. Hysteronotum bearing six pairs of setae and unpaired median hysteronotal shield lacking setae. Setae $d 1, d 2, e 1$ and $f 1$ on small platelets. Setae $h 1$ and $h 2$ smooth filiform and slightly shorter than propodonotal setae. Lengths of dorsal setae: vi 20 (22); ve 13 (12); sci 15 (12); sce 11 (11); c1 14 (12); c2 56 (62); d1 15 (12); d2 13 (13); e1 6 (6); e2 10 (10); f1 5 (5); f2 5 (5); h1 17 (16). Distances between dorsal setae: vi-vi 52 (39); sci-sci 62 (51); c1-c1 62 (51); c1-d1 70 (58); d1-d1 34 (33).

Venter (Fig. 1C) - Ventral surface ornamented with striations; bearing three pairs of setae on small platelets $(1 a, 3 a$ and $4 a)$. Genitoanal area with one pair of genital setae $(g 1)$. All ventral setae smooth and setiform. Lengths of setae: 1a 22 (18); $3 a 61$ (69); $4 a 15$ (15); g1 12 (10). Aedeagus located internally; outline visible, fine structure obscured by body.

Gnathosoma (Figs. 2B-C) - Peritremes Mshaped, with 12 pairs of chambers. Rostral shield (tegmen) with one pair of distinct lateral teeth. Gnathosoma bearing subcapitular setae $n 54$ (63) and adoral setae $a 016$ (5) and ao2 17 (14). Distance between $n-n 37$ (32). All setae smooth and setiform. Rostrum (protegmen + tegmen) ventrally and dorsally with longitudinal striations. Palp setal formula as follows: trochanter without seta; femur with one smooth seta $(d F)$ (in paratype, Fig. 2B) and one smooth setiform seta $\left(v^{\prime}\right)$ and one stout seta $\left(v^{\prime \prime}\right)$; genu with two smooth setiform setae $\left(d G, l^{\prime \prime} G\right)$; tibia with three smooth and setiform setae $\left(d T i, l^{\prime} T i\right.$, $\left.l^{\prime \prime} T i\right)$, tibial claw 39 (35) long, strong and with two basal teeth; tarsus with one comb-like eupathidium (sul) with approximately 23 tines, three smooth eupathidia $\left(a c m, u l^{\prime}, u l^{\prime \prime}\right)$ and one solenidion $(\omega)$.

Legs (Figs. 2D-G) - All leg setae smooth setiform, excluding lanceolate and serrate setae $d F$ on femora III-IV. Chaetotaxy of legs I-IV: coxae (excluding $1 a, 3 a$ and $4 a$ ) 2-1-2-1, trochanters 1-1-1-1, femora 2-2-1-1, genua $1(+1 \sigma)-1-1-0$, tibiae $4(+1 \Phi)-4(+1 \phi)-4(+1 \Phi)-4$, tarsi $9(+1 \omega)-7(+1 \omega)-7(+1 \omega)-7(+1 \omega)$. Length of solenidia: $\omega \mathrm{I} 10$ (10); $\omega \mathrm{II} 9$ (9); $\omega \mathrm{III} 10$ (9); $\omega \mathrm{IV} 9$ (8); $\phi \mathrm{I} 4$ (3); $\phi \mathrm{II}$ 


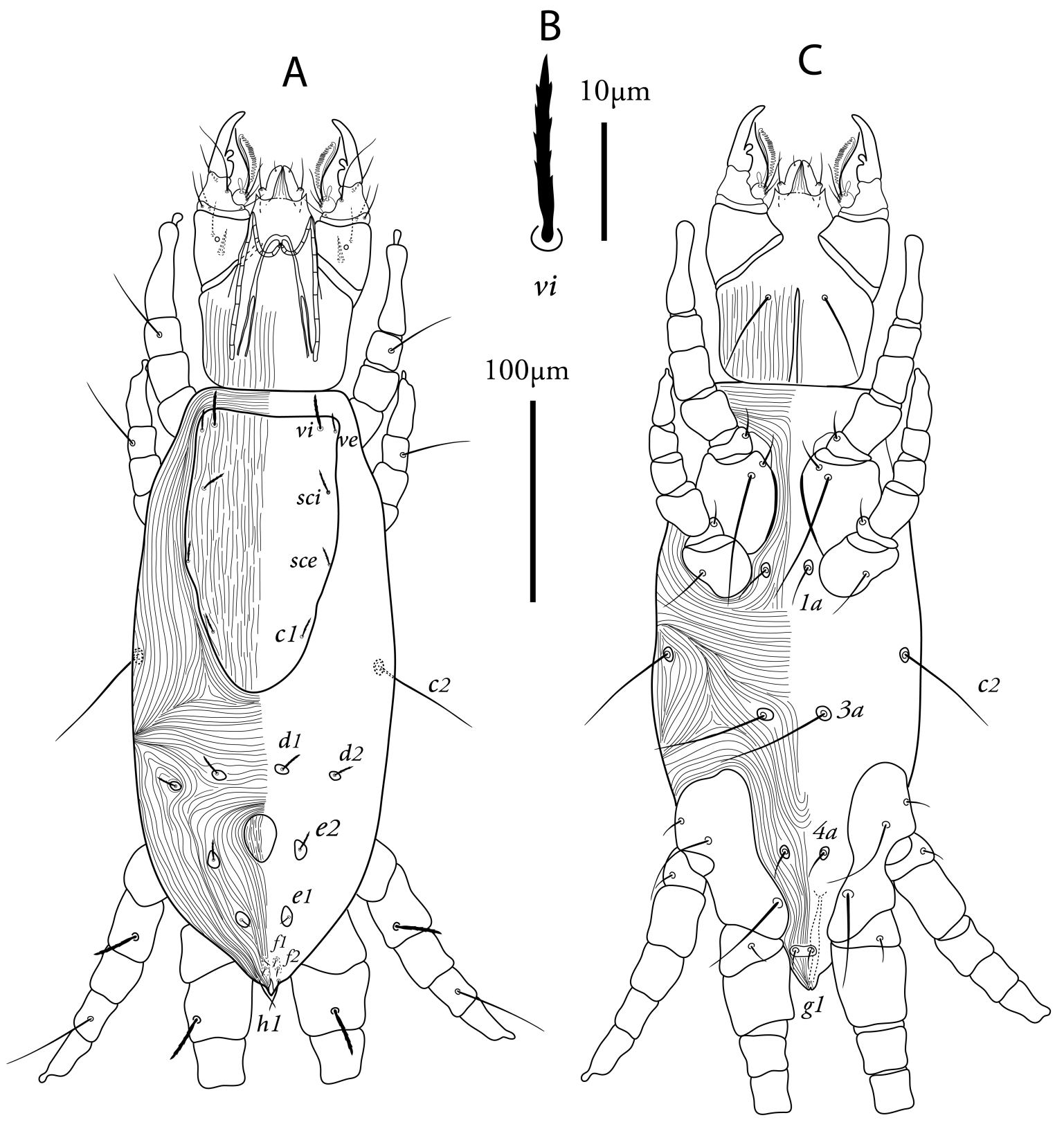

FIGURE 1: Bak iranica n. sp. (Male): A - Body in dorsal view, B - Seta vi, C - Body in ventral view. 


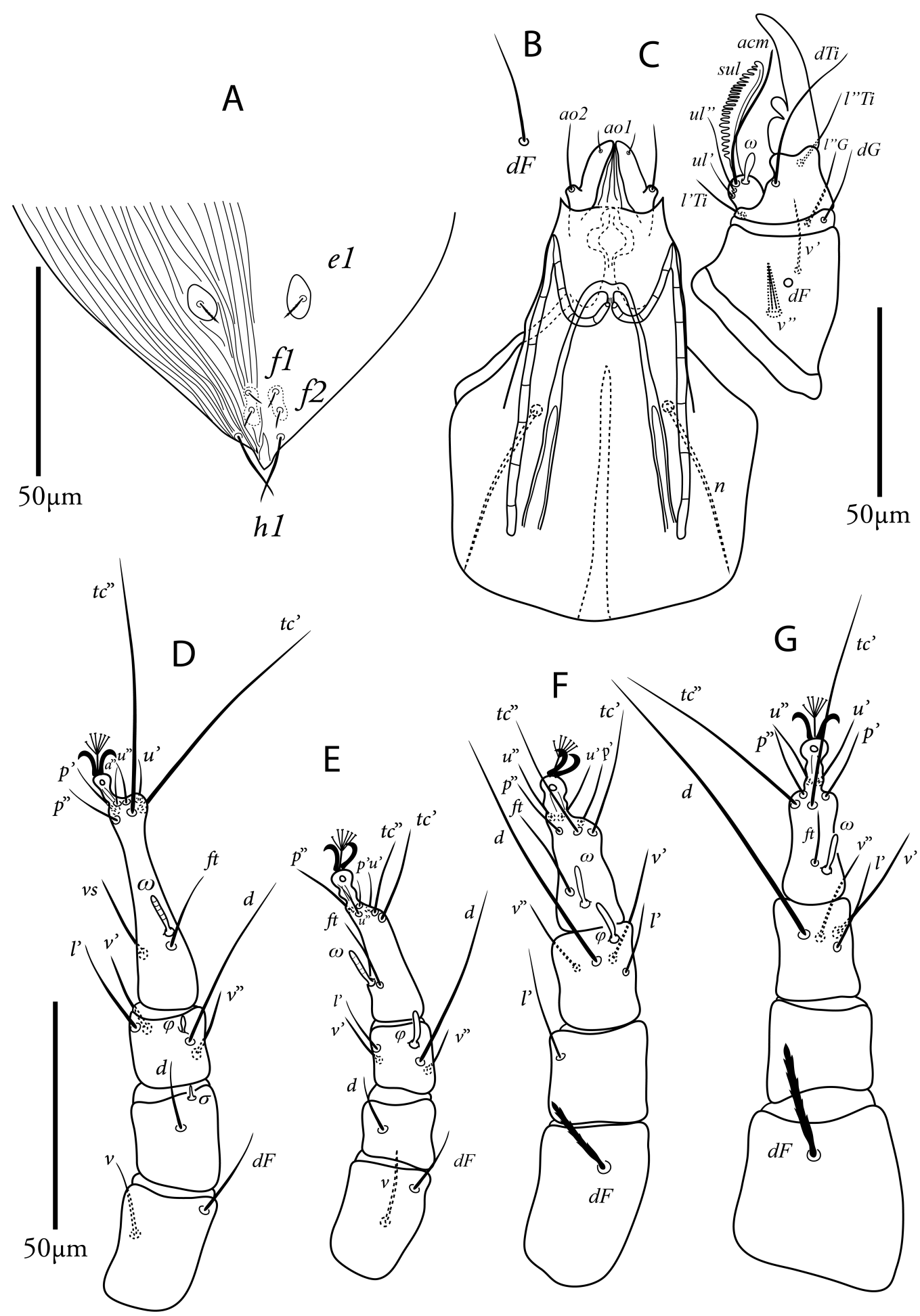

FIGURE 2: Bak iranica n. sp. (Male): A - Dorsal view of opisthosoma, B - Seta $d F$ on palp femur (paratype), C - Gnathosoma (holotype), D - Leg I, E - Leg II, F - Leg III, G - Leg IV. 
9 (10); $\phi \mathrm{III} 10$ (10).

\section{Immature stages and female: Unknown.}

Remarks - Where both sexes are known, conspecific female and male Bak specimens possess some of the same distinguishing characters, including the shape of dorsal body setae, and chaetotaxy of coxae, trochanters, femora, genua, tibia I and tarsi I-II. We therefore use these characters to distinguish $B$. iranica, which is known only by male specimens, from other Bak species, half of which are known only by female specimens.

The new species resembles B. faini Corpuz-Raros, 2000 and B. sanctaehelenae Yunker, 1961 in having the same femora and genua chaetotaxy. Bak iranica sp. nov. can be distinguished from $B$. faini by 1 ) tarsus I with 9 setae (vs. 8 setae in both sexes); 2) tibia IV without solenidion $\Phi$ (vs. solenidion $\phi$ present in male); and 3) trochanter III with one seta (vs. trochanter III without seta). Bak iranica sp. nov. differs from the males of $B$. sanctaehelenae by 1 ) palpal claw with two basal teeth instead of a single tooth; and 2) tibia IV with 4 setae and $\phi$ absent instead of $4(+1 \phi)$. Furthermore, the new species differs in the shape of dorsal body setae from $B$. indonesiensis Bochkov and Otto, 2010 as most of dorsal body setae are slightly lanceolate and barbed instead of clavate shape.

Etymology - The specific epithet is derived from the country of origin, Iran.

Type materials - Holotype and paratype males were collected from samples of soil and rotten pine leaves, Haraz road, Polour, Amol county, Mazandaran province, Iran, 11 August 2015 by Saeid Paktinat-Saeij. The holotype male is deposited in the Acarological Collection, Department of Plant Protection, Faculty of Agriculture, University of Maragheh, Maragheh, Iran, and the paratype male is deposited in the Acarological Collection, Jalal Afshar Zoological Museum, Department of Plant Protection, Faculty of Agriculture, University of Tehran, Karaj, Iran.

\section{Key to the females and males of known species of Bak}

Previously, Fain and Bochkov (2001) established a key based on characters shared by females and males. Other keys are based on females (Gerson and Fain 1991; Corpuz-Raros 2000). However, given the number of species presently known from males, we decided to provide a key for each sex separately.

1. Tibiae II-III without solenidia; inner palp tarsal comb with teeth; without aedeagus ....... female 2 - Tibiae II-III usually with one solenidion; inner palp tarsal comb usually without teeth; with an aedeagus ......................... male 12

2. Dorsal setae setiform or lanceolate ........... 3

- Dorsal setae clavate or bifurcate.............9

3. Femora I-II with one seta each ............. 4

— Femora I-II with two setae each.............5

4. Genu III nude..... B. micidus Summers and Price — Genu III with one seta.......... B. deleoni Yunker

5. Genu II nude $\ldots \ldots \ldots \ldots \ldots \ldots \ldots \ldots \ldots \ldots$

— Genu II with one seta ................... 7

6. Genu III nude.... B. ozarkensis Thewke and Enns - Genu III with one seta... B. gersoni Corpuz-Raros

7. Genu I with one seta ..................... ............. B. truncatus Corpuz-Raros and Sotto — Genu I with two setae ................... 8

8. Femur III with one seta; tarsus I with $9(+1 \omega)$ setae ........................ sanctaehelenae Yunker — Femur III with two setae; tarsus I with $8(+1 \omega)$ setae............. B. payatus Corpuz-Raros and Sotto

9. Trochanter III nude $\ldots \ldots \ldots \ldots \ldots \ldots \ldots \ldots$

— Trochanter III with one seta ...............11

10. Setae $v i$, ve and sci thickened and serrate, other dorsal setae clavate and plumose................ B. faini Corpuz-Raros - Setae vi, ve and sci clavate and plumose like other dorsal setae...... B. elongatus Diaz-Patxot and Goff

11. Dorsal setae bifurcate; tarsus I with $8(+1 \omega)$ setae B. furcatus Gerson and Fain 
— Dorsal setae clavate; tarsus I with $9(+1 \omega)$ setae . . B. indonesiensis Bochkov and Otto

12. Dorsal setae setiform or lanceolate.........13

— Dorsal setae clavate or bifurcate ........... 16

13. Genua II and III nude

................ ozarkensis Thewke and Enns

— Genua II and III each with one seta ........ 14

14. Femur III with one seta ................ 15

- Femur III with two setae .................

............ B. payatus Corpuz-Raros and Sotto

15. Tibia IV with four setae; palpal claw with two basal teeth ................... iranica n. sp. — Tibia IV with $4(+1 \Phi)$ setae; palpal claw with one basal tooth ............ B. sanctaehelenae Yunker

16. Trochanter III nude; tibia IV with $4(+1 \phi)$ setae. . . B. faini Corpuz-Raros — Trochanter III with one seta; tibia IV with four setae............................. 17

17. Dorsal setae bifurcate

B. furcatus Gerson and Fain

— Dorsal setae clavate, only seta $e 1$ bifurcate....... B. nadchatrami Fain and Bochkov

\section{ACKNOWLEDGEMENTS}

The authors wish to express their gratitude to Dr. Andre Bochkov (Zoological Institute of the Russian Academy of Sciences, Saint Petersburg, Russia) and Dr. Fariba Ardeshir (Department of Zoology, Iranian Research Institute of Plant Protection, Tehran, Iran) for their advice and literature.

\section{REFERENCES}

Bochkov A.V., Abramov V.V. 2016 - To fauna of the freeliving Cheyletidae (Acariformes: Cheyletoidea) of the European part of Russia - Syst. Appl. Acarol., 21(3): 335-346. doi:10.11158/saa.21.3.8
Bochkov A. 2005 - Synopsis of the described Actinedida of the world. Superfamily Cheyletoidea - In: Hallan J. (Ed.), Synopsis of the Described Arachnida of the World. Available from: (http:/ /insects.tamu.edu/research/collection/hallan/ acari/Family/Actinedida1.htm) (accessed 23 November 2011)

Bochkov A.V., Otto J.S. 2010 - Five new species of predaceous cheyletid mites (Acari: Cheyletidae) - Zootaxa, 2727: 1-20.

Corpuz-Raros L.A. 2000 - Two new species and a new record of Bak from the Philippines (Acari: Cheyletidae) - Int. J. Acarol., 26: 321-328. doi:10.1080/01647950008684205

Fain A., Bochkov A.V. 2001 - A review of some cheyletid genera (Acari: Prostigmata) with descriptions of new species - Acarina, 9: 47-95.

Flechtmann C.H.W. 1971 - Alguns Trombidiformes do Brasil e do Paraguai (Acari) - Escola Superior de Agricultura "Luiz de Queiroz", Universidade de Salo Paulo, Piracicaba, Brasil. pp. 63.

Gerson U., Fain A. 1991 - A new species of Bak (Acari: Cheyletidae) from Thailand, with a key to species Acarologia, 32(1): 17-21.

Grandjean F. 1939 - Les segments post-larvaires de l'hysterosoma chez les oribates (Acariens) - Bull. Soc. Zool. Fr., 64: 273-284.

Grandjean F. 1944 - Observation sur les acariens de la famillie des Stigmaeidae - Arch. Sci. phys. natur., 26: 103-131.

Kethley J. 1990 - Acarina: Prostigmata (Actinedida) In: Dindal D.L. (Ed.). Soil Biology Guide. John Wiley and Sons, New York. pp. 667-756.

Smiley R.L. 1992 - The predatory mite family Cunaxidae (Acari) of the world with a new classification - Indira Publishing House, West Bloomington, Michigan. pp. 356.

Skoracki M., Zabludovskaya S.A., Bochkov A.V. 2012 - A review of Prostigmata (Acariformes: Trombidiformes) permanently associated with birds - Acarina, 20(2): 67-107.

Walter D.E., Krantz G.W. 2009 — Collecting, rearing, and preparing specimens - In: Krantz G.W., Walter D.E. (Eds.) A Manual of Acarology. Third edition. Texas Tech University Press. pp. 83-94.

Yunker C.E. 1961 - The genera Bak, new genus, and Cheletomimus Oudemans, with descriptions of three new species (Acarina: Cheyletidae) - Can. Entomol., 93(1): 1023-1035. doi:10.4039/Ent931023-11

Zhang Z.-Q., Fan Q.-H., Pesic V., Smit H., Bochkov A.V., Khaustov A.A., Baker A., Wohltmann A., Wen T.-H, Amrine J.W., Beron P., Lin J.-Z, Gabrys G., Husband R. 
2011 — Order Trombidiformes Reuter, 1909. In: Zhang Z.-Q. (Ed.) Animal biodiversity: An outline of higherlevel classification and survey of taxonomic richness - Zootaxa, 3148: 129-138.

\section{COPYRIGHT}

(cc) EY-No-ND Paktinat-Saeij S. et al. Acarologia is under free license. This open-access article is distributed under the terms of the Creative Commons-BY-NC-ND which permits unrestricted non-commercial use, distribution, and reproduction in any medium, provided the original author and source are credited. 